\title{
Pengembangan model latihan teknik dasar sepakbola bagi anak usia 10-12 tahun di sekolah sepakbola
}

\author{
Kafung Mikail *, Suharjana \\ Program Studi Ilmu Keolahragaan, Program Pascasarjana, Universitas Negeri Yogyakarta \\ Jalan Colombo No. 1, Karangmalang, Yogyakarta 55281, Indonesia \\ *Corresponding Author. Email: kafung_michael@ymail.com
}

\begin{abstract}
Abstrak
Penelitian ini bertujuan menghasilkan model latihan teknik dasar sepakbola bagi anak usia 10-12 tahun di sekolah sepakbola (SSB) yang layak digunakan. Penelitian pengembangan ini dilakukan dengan mengadaptasi 10 langkah- langkah penelitian pengembangan sebagai berikut: (1) pengumpulan informasi di lapangan dan analisis terhadap informasi yang telah dikumpulkan, (2) mengembangkan produk awal (draf model), (3) validasi ahli dan revisi, (4) ujicoba lapangan skala kecil dan revisi, (5) ujicoba lapangan skala besar dan revisi, dan (6) pembuatan produk final. Uji coba skala kecil dilakukan terhadap 15 siswa SSB usia 10-12 tahun pada SSB Tunas Wijaya Yogyakarta. Uji coba skala besar dilakukan terhadap 30 siswa SSB usia 10 -12 tahun pada SSB Bharata. Instrumen pengumpulan data yang digunakan yaitu: (1) pedoman wawancara, (2) skala nilai, (3) pedoman observasi model, (4) pedoman observasi keefektifan model, dan (5) kuesioner untuk siswa. Teknik analisis data yang digunakan yaitu analisis deskriptif kuantitatif dan analisis deskriptif kualitatif. Hasil penelitian ini berupa model latihan sepakbola bagi anak usia 10-12 tahun di sekolah sepakbola (SSB) yang berisikan empat model latihan, yaitu: (1) latihan ball passing, (2) latihan ball controll, (3) latihan ball feeling, (4) latihan cordinationt.
\end{abstract}

Kata Kunci: latihan sepakbola; anak usia 10-12 tahun; Sekolah sepakbola; SSB

\section{Developing footbal training basic technique models for children 10-12 years old in football school}

\begin{abstract}
The purpose of this research is to invent useful football training models for children 10-12 years old in football School (SSB). This development research is carried out by adapting 10 steps of development research from Borg \& Gall (1983: 775) and make it into 6 steps as follows: (1) Collecting information on the field and analyzing the collected information, (2) developing the early product (draft model), (3) expert validation and revision, (4) small scale field trial, (5) big scale field trial and revision, and (6) final product making. The small scale trial was done toward 15 SSB trainees 10-12 years old at SSB Tunas Wijaya Yogyakarta. A Big scale trial was done to 30 SSB trainees 10-12 years old at SSB Bhantara. The data collecting instrument used are: (1) interview guide, (2) value scale, (3) model observation guide, (4) model effectiveness observation guide, and (5) questionnaires for students. Data Analysis technique that was used is quantitative descriptive and qualitative descriptive. The result of this research is a football training model for children 10-12 years old in football school (SSB) that consists of four training models, they are: (1) passing ball training, (2) ball control training, (3) ball feeling training, and (4) coordination training.
\end{abstract}

Keywords: football training; children 10-12 years old; football school

\section{PENDAHULUAN}

Pengembangan adalah proses, cara, perbuatan mengembangkan, perbuatan menjadikan bertambah, berubah sempurna. Hal ini sesuai dengan yang dikemukakan Poerwadarminta (2002, p.11) pengembangan adalah suatu proses atau cara menjadikan sesuatu maju, sempurna dan berguna. Kegiatan pengembangan meliputi tahapan: perencanaan, pelaksanaan, dan evaluasi yang diikuti 


\section{JORPRES (Jurnal Olahraga Prestasi), 15 (1), 2019 - 15}

Kafung Mikail, Suharjana

dengan kegiatan penyempurnaan sehingga diperoleh bentuk yang dianggap memadahi. Pengembangan adalah Suatu pendekatan sistematik, terpadu dan terencana untuk meningkatkan efektivitas organisasi serta memecahkan masalah-masalah (seperti kurangnya kerjasama/koperasi, desentralisasi yang berlebihan dan kurang cepatnya komunikasi dan sebagainya) yang merintangi efisiensi pengoperasian pada semua tingkatan.

Model dapat diartikan sebagai miniatur suatu objek yang didesain untuk memudahkan proses visualisasi objek yang tidak dapat diamati sehingga dapat dipahami secara sistematis. Menurut Sagala (2012, p.11) sebagai kerangka konseptual yang digunakan sebagai pedoman dalam melakukan kegiatan. Model dapat dipahami sebagai: (1) suatu tipe atau desain, (2) suatu deskripsi atau analogi, (3) suatu sistem asumsi-asumsi, data-data yang dipakai untuk menggambarkan secara sistematis suatu objek atau peristiwa, (4) suatu desain yang disederhanakan dari suatu sistem kerja, suatu terjemahan realitas yang disederhanakan, (5) suatu deskripsi dari suatu sistem yang mungkin atau imajiner, (6) penyajian diperkecil agar dapat menjelaskan dan menunjukkan sifat aslinya. Berdasarkan pernyataan Metzler (2011, p.12) someone demonstrates the way others should act or think to be a model by example. Model dapat difungsikan sebagai contoh dalam mendemonstrasikan pada orang lain tentang cara lain untuk bertindak atau berpikir.

Berdasarkan pendapat di atas dapat disimpulkan bahwa pengembangan model adalah suatu proses atau cara menjadikan sesuatu objek atau tipe menjadi lebih maju, lebih baik, sempurna, dan berguna. Secara umum model latihan dapat diartikan sebagai suatu pola atau bentuk latihan yang di dalamnya terdapat langkah-langkah latihan yang sesuai dengan tujuan latihan yang hendak dicapai.

Model latihan pada umumnya sama dengan model pembelajaran, karena pada prinsip belajar dan latihan adalah sama, yaitu untuk merubah menjadi yang lebih baik. Latihan atau pun belajar dapat dilaksankan secara teori (di dalam ruangan) ataupun peraktek (di luar ruangan). Namun, pada umumnya latihan dilaksanakan secara peraktek. Hal ini sesuai dengan yang dikemukakan McMorris dan Hale (2006, p.12) berpendapat bahwa "Learning as being a relatively permanent change in performance resulting from practice or past experience". Belajar atau berlatih adalah suatu perubahan yang relatif permanen dalam performa yang dihasilkan dari praktek atau pengalaman masa lalu.

Craig (Sukadiyanto, 2003, p.13) belajar adalah proses perubahan individu sebagai hasil dari pengalaman atau latihan melalui aktivitas yang berulang-ulang. Berdasarkan hal di atas pembahasan mengenai model latihan akan diadopsi dari model pembelajaran. Sebelum menentukan model latihan atau model pembelajaran yang akan digunakan dalam berlatih atau belajar, ada beberapa hal yang harus dipertimbangkan oleh pelatih ataupun guru. Hal ini sesuai dengan yang dikemukakan Rusman (2011, p.13) sebelum menentukan model pembelajaran yang akan digunakan dalam kegiatan pembelajaran. Ada beberapa hal yang harus dipertimbangkan guru dalam memilihnya, yaitu: (a) pertimbangan terhadap tujuan yang hendak dicapai, (b) pertimbangan yang berhubungan dengan bahan atau materi pembelajaran, (c) pertimbangan dari sudut peserta didik, dan (d) pertimbangan lainnya yang bersifat nonteknis. Secara khusus di bidang pembelajaran motorik, Samsudin (2008, p.13) mengemukakan bahwa model pembelajaran motorik adalah langkah-langkah pembelajaran dengan memerhatikan karakteristik anak, kompetensi yang akan dicapai, interaksi dalam proses pembelajaran, alat/media, dan penilaian.

Definisi tentang model di atas dapat disimpulkan bahwa model merupakan miniatur aspekaspek dalam kehidupan. Model disusun berdasarkan hasil pengamatan terhadap implementasi ilmu dalam kehidupan sehari-hari. Penyusunan model dimaksudkan untuk mempermudah transfer ilmu maupun nilai-nilai kehidupan agar dapat dipahami dan mudah diaplikasikan. Beberapa hal yang harus dipertimbangkan oleh pelatih ataupun guru sebelum menentukan model latihan atau model latihan yang akan digunakan dalam berlatih di antaranya yaitu (1) pertimbangan terhadap tujuan yang hendak dicapai, (2) pertimbangan yang berhubungan dengan bahan atau materi latihan, (3) pertimbangan dari sudut siswa, dan (4) pertimbangan lainnya yang bersifat nonteknis (Rusman, 2011, p.14).

Penyusunan model dalam penelitian dan pengembangan ini diupayakan memenuhi ciri-ciri model pembelajaran yang dituliskan oleh Rosdiani (2012, p.15) sebagai berikut: (1) berdasarkan teori belajar dari para ahli tertentu; (2) memunyai misi atau tujuan pendidikan tertentu; (3) dapat dijadikan pedoman untuk perbaikan kegiatan belajar mengajar di kelas; (4) memiliki bagian-bagian model, yaitu syntax (urutan langkah-langkah pembelajaran), adanya prinsip-prinsip reaksi, sistem sosial, dan sistem pendukung; (5) memiliki dampak sebagai akibat terapan model pembelajaran. Dampak tersebut meliputi dampak pembelajaran, yaitu hasil belajar yang dapat diukur, dan dampak pengiring, yaitu 


\section{JORPRES (Jurnal Olahraga Prestasi), 15 (1), 2019 - 16}

Kafung Mikail, Suharjana

hasil belajar jangka panjang; dan (6) membuat persiapan mengajar (desain intruksional) dengan pedoman model pembelajaran yang dipilihnya.

Berdasarkan pendapat tersebut, maka disimpulan bahwa model latihan dalam penelitian ini adalah sebuah desain latihan yang disusun sedemikian rupa secara sistematis dalam mengorganisasikan pengalaman belajar untuk mencapai kompetensi/tujuan latihan yang diharapkan. Latihan merupakan suatu proses berlatih yang sistematis yang dilakukan secara berulang-ulang, dan yang semakin hari jumlah beban latihannya semakin bertambah (Giriwijoyo, et al., 2005, p.16). Sedangkan menurut Suharno (Irianto, 2002, p.16) latihan merupakan suatu proses mempersiapkan organisme atlet secara sistematis untuk mencapai mutu prestasi maksimal dengan diberikan beban fisik dan mental yang teratur, terarah, meningkat, dan berulang-ulang waktunya. Berdasarkan pendapat tersebut, dapat diartikan bahwa latihan yaitu sebuah proses yang sistematis untuk meningkatkan kemampuan seseorang dengan pemberian beban latihan secara berulang-ulang. Sistematis berarti bahwa pelatihan dilaksanakan secara teratur, berencana, menurut jadwal, menurut pola dan sistem tertentu, metodis, bersinambungan dari yang sederhana ke yang lebih kompleks. Latihan yang tidak memenuhi salah satu dari hal tersebut bukanlah latihan yang dilaksanakan secara sistematis. Sedangkan berulang-ulang dapat diartikan bahwa gerakan yang dipelajari harus dilatih berulang-ulang agar gerakan yang semula sukar dilakukan dan koordinasi gerakan yang masih kaku menjadi kian mudah, otomatis, dan reflekstif pelaksanaannya. Selain itu dapat memperhalus koordinasi gerakan sehingga semakin menghemat energi (efisien).

Menurut Sukadiyanto \& Muluk (2011, p.17) latihan adalah suatu proses penyempurnaan kemampuan berolahraga yang berisikan materi teori dan praktik, menggunakan metode dan aturan, sehingga tujuan dapat tercapai tepat pada waktunya yang memiliki ciri-ciri sebagai berikut: (1) suatu proses untuk mencapai tingkat kemampuan yang lebih baik dalam berolahraga, yang memerlukan waktu tertentu (pentahapan), serta memerlukan perencanaan yang tepat dan cermat; (2) proses latihan harus teratur dan progresif. Teratur maksudnya latihan harus dilakukan secara ajeg, maju, dan berkelanjutan. Sedangkan bersifat progresif maksudnya materi latihan diberikan dari yang mudah ke yang sukar, dari yang sederhana ke yang lebih sulit (kompleks), dari yang ringan ke yang berat; (3) pada setiap kali tatap muka (satu sesi/satu unit latihan) harus memiliki tujuan dan sasaran; (4) materi latihan harus berisikan materi teori dan praktik, agar pemahaman dan penguasaan keterampilan menjadi relatif permanen; dan (5) menggunakan metode tertentu, yaitu cara paling efektif yang direncanakan secara bertahap dengan memperhitungkan faktor kesulitan, kompleksitas gerak, dan penekanan pada sasaran latihan.

Bompa \& Haff (2009, p.19) menjelaskan bahwa sasaran latihan meliputi (1) perkembangan fisik multilateral, dimana atlet memerlukan pengembangan fisik secara menyeluruh berupa kebugaran (fitness) sebagai dasar pengembangan aspek lainnya yang diperlukan untuk mendukung prestasi; (2) perkembangan fisik khusus cabang olahraga, dimana setiap atlet memerlukan persiapan fisik khusus sesuai dengan cabang olahraganya; (3) keterampilan teknik, dimana kemampuan biomotor seorang atlet dikembangkan berdasarkan kebutuhan teknik cabang olahraga tertentu untuk meningkatkan efisiensi gerakan; (4) kemampuan taktik, dimana siasat untuk memenangkan pertandingan merupakan bagian dari tujuan latihan dengan memertimbangkan kemampuan lawan, kekuatan dan kelemahan lawan, serta kondisi lingkungan; (5) faktor psikologis, dimana faktor psikologis digunakan untuk meningkatkan disiplin, semangat, daya juang, kepercayaan diri, dan keberanian; (6) memelihara kesehatan, dimana kesehatan merupakan bekal yang perlu dimiliki seorang atlet, sehingga perlu pemeriksaan secara teratur dan perlakuan dalam mempertahankannya; (7) pencegahan cedera, merupakan sesuatu yang sangat ditakuti atlet, sehingga perlu upaya pencegahan melalui peningkatan kelentukan sendi, kelenturan dan kekuatan otot; dan (8) pengetahuan teoritis, dimana latihan harus memperbaiki pengetahuan atlet tentang dasar fisiologis dan psikologis dari latihan, perencanaan, nutrisi, dan regenerasi. Menurut Suharjana (2013, p.20) tujuan latihan di antaranya adalah untuk mencapai dan memperluas perkembangan dan pertumbuhan fisik secara menyeluruh bagi anak usia perkembangan, meningkatkan karakter pribadi seperti kedisiplinan, semangat, bersungguh-sungguh, mengembangkan kepercayaan diri, tenggang rasa dengan teman, melatih rasa sosial dan kerja sama apabila dilihat dari esensi pendidikan, serta menguatkan persendian dan ligamentum sehingga terhindar dari cedera bagi atlet. 


\section{JORPRES (Jurnal Olahraga Prestasi), 15 (1), 2019 - 17}

Kafung Mikail, Suharjana

\section{Pentahapan Latihan}

Latihan merupakan proses yang panjang dan lama sehingga latihan harus dilakukan secara sistematis dengan membagi beberapa tahap, yaitu:

\section{Tahap Latihan Dasar}

Merupakan tahapan yang harus dilalui atlet muda sebelum melangkah ke tahap latihan selanjutnya. Tahap ini harus dilewati atlet sebelum masuk dalam spesialisasi cabang olahraga yang akan ditekuni. Latihan yang dilakukan pada tahap ini harus berprinsip pada multilateral sehingga atlet dapat diidentifikasi bakatnya sejak muda. Hal yang sangat penting dalam tahapan ini adalah untuk menyiapkan landasan yang baik bagi atlet muda yang berkaitan dengan aspek fisik, mekanik, psikologi dan moral sebagai prakondisi untuk pencapaian hasil yang baik melalui kemampuan pengembangan, keterampilan, dan karakter. Sasaran yang harus dicapai dalam tahapan ini adalah pengembangan kondisioning dan koordinasi, pengembangan pola gerak dasar olahraga yang akan ditekuni, kesiapan berlatih dan pembentukan kepribadian, menanamkan pengalaman berlatih dan bertanding dengan sikap yang baik, serta menemukan bakat atlet dan mengembangkannya.

\section{Tahap Latihan Lanjut}

Merupakan tahap penghubung yang menghubungkan tahap latihan dasar dengan tahap prestasi tinggi. Hal yang perlu diperhatikan dalam tahapan ini adalah untuk memperkuat fondasi keterampilan, kualitas, dan kemampuan fisik dan melakukan latihan yang lebih khusus (spesialisasi) pada cabang olahraga yang akan ditekuni. Tahapan ini dimulai saat usia 14 tahun pada cabang-cabang olahraga tertentu. Sasaran yang harus dicapai dalam tahap latihan ini adalah memperkuat kemauan (will power) untuk berlatih dan menghadapi berbagai kendala psikologis dan fisik, mengembangkan harmonisasi kondisi fisik dengan koordinasi (seperti kekuatan, kecepatan, daya tahan, kelincahan dan mobilitas) untuk menuju spesialisasi cabang olahraga dengan pendasaran fisik yang kuat menuju prestasi tinggi nantinya, dan pengembangan latihan teknik dan taktik dengan melakukan uji coba latihan dan pertandingan yang lebih sering.

\section{Tahap Prestasi Tinggi}

Tahap ini merupakan tahap terakhir dari seluruh tahap latihan. Tujuan dalam tahap prestasi tinggi adalah menyiapkan kemampuan atlet dalam mengikuti kejuaraan nasional dan internasional. Sasaran dalam tahap ini adalah prestasi tinggi.

\section{Pembebanan Latihan dan Unsur-unsur beban}

Setiap latihan memiliki empat indikator, yaitu fisik, teknik, taktik, dan mental. Harmonisasi dari keempat indikator tersebut akan dapat memberikan kontribusi terhadap pencapaian prestasi. Keempat indikator tersebut dapat diimplementasikan dengan indikator dan karakteristik yang berbeda, tergantung dari kebutuhan cabang olahraga yang ditekuni.

\section{Indikator beban}

Indikator beban latihan dapat dilihat untuk menentukan berat atau ringannya suatu latihan, yaitu dengan memerhatikan volume (jumlah pembebanan dalam satuan $\mathrm{km}, \mathrm{m}, \mathrm{kg}$, dan waktu dalam detik), intensitas (persentase beban dari kemampuan maksimal), dan pemulihan/recovery (waktu atau bentuk kegiatan yang diperlukan untuk melakukan pulih asal setelah melakukan pembebanan, baik dalam seri, set maupun antar sesi). Perbandingan antara intensitas, volume, dan pemulihan disusun sebaiknya sesuai dengan periode dan fase latihan, tujuan latihan yang hendak dicapai dan berat ringannya latihan.

\section{Teknik Dasar Sepakbola}

Teknik sepakbola bagi pemain pemula agar dapat bermain sepakbola cukup dengan melakukan gerakan-gerakan/teknik-teknik yang sederhana seperti gerakan tanpa bola yang meliputi lari dan melompat, dan gerakan dengan bola yang meliputi menendang, menahan bola, mengontrol bola dan menggiring bola. Teknik bermain sepakbola adalah semua gerakan-gerakan tanpa bola dan gerakangerakan dengan bola yang diperlukan dalam bermain sepakbola, jadi teknik bermain sepakbola merupakan kemampuan untuk melakukan gerakan-gerakan atau mengerjakan sesuatu yang diperlukan 


\section{JORPRES (Jurnal Olahraga Prestasi), 15 (1), 2019 - 18}

Kafung Mikail, Suharjana

dalam permainan sepakbola, maka untuk dapat bermain sepakbola dengan baik sebelumnya harus menguasai teknik dasar sepakbola terlebih dahulu.

Penguasaan keterampilan teknik dasar menentukan kemahiran seseorang dalam melakukan keseluruhan gerak dalam suatu cabang olahraga. Oleh karena itu, seorang olahragawan harus mampu menguasai teknik dasar dengan baik dan benar. Menurut Giriwijoyo, dkk. (2005, p.28) latihan teknik merupakan latihan yang bertujuan untuk mempermahir penguasaan keterampilan gerak dalam suatu cabang olahraga, misalnya teknik menendang, melempar, menangkap, menggiring bola, dan melompat. Oleh karena seseorang pemain yang memiliki penguasaan teknik yang efisien dan efektif memiliki beberapa keuntungan di antaranya yaitu akan menghindarkan dari kerja yang berlebihan, memperkecil kemungkinan terjadi cedera, merupakan dasar yang kuat untuk pengembangan teknik tingkat selanjutnya, serta mampu melakukan tugas secara konsisten.

Pemain yang memiliki teknik yang baik cenderung pemain tersebut dapat memainkan sepakbola yang baik pula. Menurut Subroto, dkk. (2009, p.29) teknik-teknik dalam permainan sepak bola dapat dikelompokkan menjadi dua, yaitu teknik tanpa bola dan teknik dengan bola. Pendapat ini juga dipertegas oleh Suwarno (2001, p.29) yang menyatakan bahwa permainan sepakbola mencakup dua kemampuan dasar gerak atau teknik yang harus dimiliki atau dikuasai oleh pemain yaitu gerak teknik dengan bola dan gerak teknik tanpa bola.

\section{Teknik tanpa bola}

Teknik tanpa bola yaitu semua gerakan-gerakan tanpa bola yang meliputi lari cepat merubah arah, melompat atau meloncat, gerak tipu dengan badan dan gerakan khusus penjaga gawang. Teknik tanpa bola dapat dibagi menjadi beberapa bagian, yaitu: (1) lari, merupakan hal yang sangat penting bagi pemain sepakbola, yang merupakan ciri khas bagi pemain sepakbola adalah lari dengan langkahlangkah pendek, hal ini agar kaki jangan terlalu jauh dari poros tubuh; (2) melompat, merupakan salah satu usaha untuk mengambil bola yang lebih tinggi yang tidak mungkin diambil menggunakan kaki; (3) tackling (merampas bola), merupakan usaha merampas bola pada saat bola dimainkan oleh pihak lawan; (4) body charge, merupakan usaha mendorong lawan dengan menggunakan samping badan pada lengan; dan (5) teknik penjaga gawang, yaitu teknik penempatan posisi di bawah mistar gawang.

\section{Teknik dengan bola}

Teknik dengan bola merupakan suatu gerakan-gerakan dengan bola. Teknik dengan bola terdiri dari menendang bola, menggiring bola, menyundul bola, menahan dan mengontrol bola, melempar bola, dan teknik penjaga gawang.

Penguasaan gerak teknik sangat diperlukan oleh pemain untuk dapat meraih prestasi dalam permainan sepakbola. Menurut Sucipto, dkk. (2000, p.30) teknik dasar sepakbola meliputi: (1) menendang (kicking), (2) menggiring (dribbling), (3) menyundul (heading), (4) menghentikan (stopping), (5) merampas (tackling), (6) lemparan ke dalam (throw-in), dan (7) menjaga gawang (keeping).

Kegunaan dari masing-masing teknik dasar dengan bola di antaranya yaitu menendang bola biasanya digunakan untuk mengoper bola (passing), mencetak gol (shooting), membersihkan bola dari daerah bahaya, tendangan khusus (penalti, tendangan bebas, tendangan sudut, dan tendangan gawang). Teknik menerima bola digunakan untuk mengontrol bola, baik bola menyentuh tanah, memantul, maupun bola di udara, agar bola tetap dalam penguasaan pemain tersebut. Teknik menggiring bola digunakan untuk tujuan melewati lawan, mencari kesempatan untuk mengumpan kepada rekan tim, dan menahan bola agar tetap dalam penguasaan atau mengatur tempo permainan. Teknik menyundul bola digunakan dengan tujuan untuk mengoper bola, mencetak gol, membersihkan serangan lawan, serta meneruskan bola.

Berdasarkan dari cara melakukannya, teknik dasar dengan bola dapat dibedakan menjadi: (1) teknik passing, (3) teknik controll, (3) teknik ball feeling (4) teknik coordination.

\section{Teknik Passing}

Passing adalah cara mengoper bola kepada teman satu tim. Kebanyakan orang melakukan passing menggunakan kaki bagian dalam karena pada kaki bagian dalam terdapat permukaan yang lebih luas bagi pemain untuk menendang bola, sehingga memberi kontrol bola yang lebih baik. Cara melakukan passing menggunakan kaki bagian dalam yaitu: a. Posisikan badan menghadap ke arah 


\section{JORPRES (Jurnal Olahraga Prestasi), 15 (1), 2019 - 19}

Kafung Mikail, Suharjana

mana bola akan dituju. Posisi ini dimaksudkan agar dalam menendang bola lebih dapat mengontrol dan menendang dengan baik. b. Tarik kaki yang akan menendang ke belakang. Saat menarik kaki kebelakang itu adalah saat dimana kita akan menentukan seberapa kuat bola di tendang. Biasanya semakin jauh tarikan, maka akan semakin jauh juga bola kita tendang.c. Sentuhlah bola dengan mengunakan kaki bagian dalam.d. Follow Throw ( gerakan Lanjutan ) adalah gerakan akhir setelah kita melakukan sentuhan dengan bola, gerakan ini berfungsi untuk tidak membuat gerakan menjadi kaku dan enak dilihat. Hampir semua olahraga memiliki gerakan follow throw.

\section{Teknik Controll}

Kontrol bola sering disebut juga receiving dalam bahasa inggris atau menahan bola, merupakan gerakan terkontrol dengan konsetrasi tinggi untuk menerima operan dari kawan hingga bola siap untuk dipakai dan dilanjutkan. Ada 4 elemen kunci dari kontrol bola yang baik: (a) Sentuhan pertama penerima harus melindungi bola dari pemain yang menyerang dan tidak memberi mereka kesempatan untuk mendapatkan bola kembali, (b) Pemain penerima harus memainkan bola ke ruang kosong yang tersedia untuk memungkinkan sentuhan berikutnya dan untuk mendapatkan atau menjaga momentum. (c) Kontrol bola adalah untuk menempatkan permukaan anggota ke garis laju bola. Berat badan harus terdistribusi dengan baik sehingga memungkinkan untuk bergerak maju, mundur atau ke samping. Jaga kepala mantap dan melihat bola secara cermat untuk menilai arah dan kecepatan laju bola. Sulit untuk menjaga mata seseorang secara permanen kearah bola dan pemain yang lebih baik dapat mengambil sekilas untuk mengetahui apa yang terjadi di sekitar mereka sebelum kontak dibuat, d. Kontrol Wedge melibatkan permukaan yang lebih kaku di mana pemain mencoba untuk memaksa bola kebawah atau ke ruang sehingga dia bisa bergerak ke arahnya. Kontrol empuk lembut atau mengambil benturan dari bola dengan menarik permukaan kembali saat kontak dengan bola (tubuh menjadi elastis) sehingga seolah bola menempel di kaki pemain. Teknik khusus ini sangat berguna ketika di marking dengan ketat, misalnya ke depan menerima bola di dada saat membelakangi gawang lawan.

Anggota tubuh yang berbeda sering digunakan dalam mengontrol bola adalah: kaki (Sole, dalam, luar, punggung kaki), paha, dada \& perut dan kepala.

\section{Latihan Ball Feeling}

Dalam sepakbola salah satu factor untuk dapat mewujudkan prestasi secara optimal adalah penguasaan bola ini berarti jika faktor-faktor pendukung lainnya dianggap cukup menunjang.

Kemampuan menguasai bola yang sulit dengan cepat dan cermat bukan saja memberi kepuasan pada diri sendiri, melainkan juga sebagai tontonan yang sangat menarik sehingga dengan demikian semakin banyak bagian tubuh yang dapat digunakan untuk menguasai bola secara baik maka semakin baik pula mutu permainannya.

(Coerver 1985, p.34) seorang pakar sepakbola asal Belanda pernah menangani Tim Nasional Indonesia beberapa tahun yang lalu pernah menyatakan, bahwa pemain yang memiliki kemampuan baik dalam ball feeling maka pemain tersebut akan lebih muda melakukan teknik-teknik baru dalam sepakbola. Tindakan terpenting dalam latihan teknik, termasuk latihan teknik menendang mengontrol dan sebagainya adalah berusaha agar seorang pemain dapat menyatu dengan bola.

\section{Latihan Koordinasi}

Koordinasi adalah suatu kemampuan biomotorik yang sangat kompleks (Harsono 1988, p.36). Selanjutnya (Sajoto 1995, p.36) koordinasi adalah kemampuan seseorang mengintegrasikan bermacam-macam gerakan yang berbeda kedalam pola gerakan tunggal secara efektif. Setiap orang untuk dapat melakukan gerakan atau keterampilan baik dari yang mudah, sederhana sampai yang rumit diatur dan diperintah dari sistem syaraf pusat yang sudah disimpan di dalam memori terlebih dahulu. Jadi untuk dapat melakukan gerakan koordinasi yang benar diperlukan juga koordinasi sistem syaraf yang meliputi sistem syaraf pusat dan sistem syaraf tepi dengan otot, tulang, dan sendi.

Menurut Lutan, dkk (2000, p.37), koordinasi adalah kemampuan untuk melakukan gerakan dengan berbagai tingkat kesukaran dengan cepat dan efisien dan penuh ketepatan. Koordinasi diperlukan hampir disemua cabang olahraga yang melibatkan kegiatan fisik, koordinasi juga penting bila berada dalam situasi dan lingkungan yang asing, misalnya perubahan lapangan pertandingan, peralatan, cuaca, lampu penerangan, dan lawan yang dihadapi. Tingkatan baik atau tidaknya 


\section{JORPRES (Jurnal Olahraga Prestasi), 15 (1), 2019 - 20}

Kafung Mikail, Suharjana

koordinasi gerak seseorang tercermin dalam kemampuannya untuk melakukan suatu gerakan secara mulus, tepat, cepat, dan efisien.

Seorang atlet dengan koordinasi yang baik bukan hanya mampu melakukan suatu keterampilan secara sempurna, akan tetapi juga mudah dan cepat dalam melakukan keterampilan yang masih baru baginya. Koordinasi yang baik dapat mengubah dan berpindah secara cepat dari pola gerak satu kepola gerak yang lain sehingga gerakannya menjadi efektif.

Menurut Bompa dalam (Sukadiyanto 2005, p.37) pada dasarnya koordinasi dibedakan menjadi dua macam, yaitu koordinasi umum dan koordinasi khusus. Koordinasi umum merupakan kemampuan seluruh tubuh dalam menyesuaikan dan mengatur gerakan secara simultan pada saat melakukan suatu gerak. Koordinasi khusus merupakan koordinasi antar beberapa anggota badan, yaitu kemampuan untuk mengkoordinasikan gerak dari sejumlah anggota badan secara simultan.

\section{METODE}

Jenis penelitian yang dipergunakan pada penelitian ini adalah research and development atau penelitian pengembangan. Penelitian pengembangan ini dilaksanakan untuk mendapatkan sebuah model latihan teknik dasar sepakbola passing, controll, ball feeling dan coordinationt bagi anak usia 10-12 tahun. Penelitian dengan model pengembangan dipilih, karena penelitian pengembangan yang dilakukan ini berorentasi pada produk, sehingga produk yang dihasilkan diharapkan dapat sesuai dengan anak usia 10-12 tahun dalam latihan teknik dasar sepakbola dengan model latihan passing, controll, ball feeling dan coordinationt.

Prosedur Pengembangan

Sepuluh langkah dalam prosedur penelitian research and development, menurut langkahlangkah penelitian research and development adalah (1) potensi dan masalah, (2) pengumpulan data, (3) desain produk, (4) validasi desain, (5) revisi desain, (6) uji coba produk, (7) revisi produk, (8) uji coba pemakaian, (9) revisi produk, dan (10) produksi masal.

Jenis data yang diperoleh dalam penelitian dan pengembangan ini yaitu data kualitatif dan data kuantitatif. Data kualitatif berasal dari: (a) hasil wawancara dengan ahli materi, pakar atau pelatih sepakbola, (b) data kekurangan model latihan passing, control, ball feeling, coordination dari ahli materi dan pelatih sepakbola pelaku uji coba, dan (c) data masukan ahli materi dan pelatih sepakbola pelaku uji coba terhadap model latihan passing, control, ball feeling dan coordination. Data kuantitatif diperoleh dari: (a) penilaian ahli materi terhadap latihan passing, control, ball feeling dan coordination dan (b) penilaian ahli materi terhadap keefektifan latihan passing, control, ball feeling dan coordination.

Instrumen adalah alat ukur yang digunakan untuk memperoleh data penelitian. Instrumen yang digunakan dalam penelitian pengembangan ini adalah:

\section{Wawancara}

Teknik pengumpulan data pertama yang digunakan yaitu teknik komunikasi langsung dengan menggunakan instrumen wawancara sebagai alat pengumpul data. Bentuk wawancara yang dilakukan yaitu wawancara bebas terpimpin, dalam pelaksanaannya, pewawancara membawa pedoman yang hanya merupakan garis besar tentang hal-hal yang akan ditanyakan pada responden. Pedoman wawancara tidak berbentuk seperangkat pertanyaan, namun hanya berbentuk butir-butir pertanyaan yang perlu di sampaikan, yang disusun berdasarkan masalah, sub masalah dan variabel penelitian.

Selanjutnya perlu ditekankan bahwa dalam penggunaan wawancara sebagai alat pengumpul data, tidak pernah digunakan perhitungan statistika untuk mengetahui validitas dan reliabilitasnya. Penentuan validitas dan reliabilitas wawancara tidak dilakukan secara empiris, tetapi melalui analisis isi, yang mengaitkan relevansi antara pertanyaan-pertanyaan dalam pedoman wawancara dengan variabel yang hendak diungkap dalam suatu penelitian. Selain itu, terkait dengan etika penelitian yang berkenaan dengan kerahasiaan, untuk menjaga kerahasiaan, maka nama responden, tempat, institusi, dan aktivitas seoptimal mungkin akan diganti dengan nama lain.

Pertanyaan yang disusun dalam pedoman wawancara disesuaikan dengan tujuan pelaksanaan wawancara yaitu untuk menggali proses model latihan sepakbola di SSB dan masalah-masalah yang dihadapi pelatih terkait latihan tersebut, untuk mendukung latar belakang masalah penelitian. Butirbutir pertanyaan tersebut meliputi: (1) lama melatih di SSB (2) waktu dan lama latihan SSB, (3) sarana 
Kafung Mikail, Suharjana

dan prasarana apa saja yang ada dan dimiliki sekolah Sepakbola, (4) sudah berapa lama anak pada usia 10-12 tahun mengikuti latihan di SSB, (5) bentuk penilaian yang dilakukan oleh pelatih khususnya dalam peningkatan kemampuan, (6) cara pelatih memberikan metode latihan, (7) aspek-aspek yang paling mendasar dalam bermain sepakbola, (8) cara pelatih dalam meningkatkan teknik dasar anak, (9) bagaimana pelatih memberikan permainan pada anak waktu melaksanakan latihan, (10) perlu tidak dikembangkannya model latihan teknik dasar sepakbola bagi anak usia 10-12 tahun.

Angket

Instrumen pengumpul data kedua yang digunakan yaitu angket dengan menggunakan skala nilai (Rating Scale). Skala nilai ini digunakan untuk menilai kelayakan model latihan sepakbola yang dikembangkan sebelum pelaksanaan uji coba skala kecil. Setelah para ahli materi menilai bahwa model latihan tersebut sudah sesuai dengan unsur-unsur dalam skala nilai, model baru dapat diujicobakan dalam uji coba skala kecil.

Dalam skala nilai, variabel atau tujuan penelitian diklasifikasikan secara rinci menjadi gejalagejala dengan unsur-unsurnya. Klasifikasi tersebut disusun ke bawah, sedangkan ke samping dicantumkan kategori sesuai dengan maksud/tujuan penelitian, antara lain berupa urutan kualitas data yang dikumpulkan. Kategori yang dimaksud dalam skala penilaian ini adalah kategori berskala dua, yaitu sesuai dan tidak sesuai.

Cara penggunaan skala nilai yaitu, bilamana muncul gejala atau unsur-unsur seperti yang terdapat dalam klasifikasi data, para pakar dan pelatih memberikan tanda cek $(\sqrt{ })$ pada kolom kategori yang sesuai. Apabila gejala atau unsur seperti yang terdapat dalam klasifikasi data dinyatakan sesuai maka nilainya satu (1), apabila dinyatakan tidak sesuai maka nilainya nol (0).

Sebagaimana tujuan penelitian ini yaitu untuk mengembangkan model latihan teknik dasar sepakbola bagi anak usia 10-12 tahun di SSB, berikut ini diuraikan klasifikasi unsur-unsurnya: (1) model latihan sesuai dengan tujuan latihan sepakbola, (2) model latihan mengandung konsep passing, control, ball feeling dan coordination, (3) model latihan ini dapat meningkatkan kemampuan penguasaan bola anak dengan baik, (4) latihan mendorong kemampuan keterampilan penguasaan bola dengan baik, (5) model latihan sesuai dengan karakteristik anak-anak, (6) model latihan ini dapat meningkatkan kegembiraan pada siswa, (7) model latihan mudah untuk dimainkan dan dimengerti oleh anak. (8) model latihan tidak mengandung resiko cedera, (9) petunjuk model latihan yang diberikan jelas, dan (10) model latihan mudah untuk dimainkan dan dimengerti oleh anak.

\section{Instrumen Observasi}

Teknik pengumpulan data ketiga yang digunakan yaitu teknik observasi tidak langsung dengan instrumen observasi berupa daftar cek (check list) menggunakan skala likert dan DVD rekaman pelaksanaan model latihan teknik dasar sepakbola bagi anak usia 10-12 tahun pada uji coba lapangan baik skala kecil/skala besar. Teknik observasi tidak langsung merupakan cara mengumpulkan data yang dilakukan melalui pengamatan dan pencatatan gejala-gejala yang tampak pada objek penelitian yang dilaksanakan setelah peristiwa atau situasi atau keadaannya terjadi.

Dalam pengukuran sering terjadi kecenderungan responden memilih jawaban pada kategori 3 (tiga) untuk skala likert. Untuk mengatasi hal tersebut skala likert hanya menggunakan 4 (empat) pilihan, agar jelas sikap dari responden. Instrumen observasi yang digunakan dalam penelitian ini menggunakan skala likert dengan 4 pilihan kategori jawaban yaitu: sangat setuju (skor 4), setuju (skor 3), tidak setuju (skor 2), dan sangat tidak setuju (skor 1).

\section{Rekonstruksi Instrumen Observasi Untuk Para Ahli Materi}

Berikut ini dilakukan rekonstruksi instrumen observasi berupa daftar cek. Unsur-unsur yang disusun dalam daftar cek adalah unsur-unsur yang berkaitan dengan hakikat tujuan model latihan teknik dasar sepakbola bagi anak usia 10-12 tahun, meliputi: (1) Kesesuaian model dengan karakteristik usia 10-12 tahun, (2) Petunjuk latihan jelas untuk dipahami, (3) Pemilihan metode latihan ini tepat pada tujuan dan sasaran, (4) Alat dan fasilitas yang digunakan sesuai tujuan, (5) Model latihan mendorong keterampilan penguasaan bola dengan baik, (6) Model latihan mudah untuk dilakukan, (7) Model latihan memberikan rasa gembira bagi siswa SSB, (8) Model latihan ini dapat mendorong siswa terampil bermain sepakbola, (9) Model latihan ini dapat meningkatkan penguasaan bola siswa SSB lebih baik, (10) Model latihan aman dilaksanakan dalam proses latihan. 


\section{Instrumen Penilaian Anak}

Instrumen penilaian anak adalah format penilaian yang digunakan pelatih untuk menilai kinerja anak saat melaksanakan latihan yang dikembangkan. Dengan format penilaian ini akan memudahkan pelatih dalam mengevaluasi penampilan anak dan ketercapaian indikator yang diharapkan dari tiap latihan. Terdapat 9 format penilaian untuk 4 latihan yang dikembangkan. Format penilaian untuk masing-masing permainan berbeda karena indikator tujuan latihan yang berbeda-beda dalam tiap latihan. Kisi-kisi format penilaian anak sama dengan kisi-kisi instrumen untuk mengobservasi keefektifan model latihan.

\section{HASIL DAN PEMBAHASAN}

Analisis kebutuhan merupakan cara yang dilakukan untuk mengurai pokok masalah melalui peninjauan langsung di lapangan. Pada penelitian pengembangan model latihan sepakbola bagi anak usia 10-12 tahun di sekolah sepakbola SSB analisis kebutuhan dilakukan dengan melakukan observasi di SSB. Observasi dilakukan dengan beberapa metode seperti wawancara terhadap pelatih dan melihat langsung metode latihan yang diajarkan pada siswa SSB.

Berdasarkan observasi yang dilakukan diperoleh beberapa informasi diantaranya, siswa SSB usia 10-12 tahun merasakan bosan terhadap jenis latihan yang dilakukan. Minimnya model latihan sepakbola. Berdasarkan permasalahan yang ada maka akan dikembangkan model latihan teknik dasar sepakbola bagi anak usia 10-12 tahun. Data model latihan dengan dengan latihan ball passing dan ball controll.

Tabel 1. Data Hasil Observasi Uji Coba Skala Besar Model Latihan Dengan Latihan Menggunakan Cone, Ball Passing and Ball Controll

\begin{tabular}{lcccccccccccc}
\hline & \multicolumn{1}{c}{ Ahli Materi } & 1 & 2 & 3 & 4 & 5 & 6 & 7 & 8 & 9 & 10 & Total Nilai \\
\cline { 2 - 13 } & 4 & 4 & 4 & 4 & 4 & 4 & 4 & 4 & 4 & 4 & 40 \\
Pakar 1 & 4 & 4 & 4 & 4 & 4 & 4 & 4 & 4 & 4 & 4 & 40 \\
Pakar 2 & 4 & 4 & 3 & 4 & 4 & 4 & 3 & 4 & 4 & 4 & 38 \\
Pakar 3 & 4 & 4 & 3 & 4 & 4 & 4 & 4 & 4 & 4 & 4 & 39 \\
Pelatih SSB 1 & 4 & 4 & 3 & 4 & 4 & 4 & 4 & 4 & 4 & 4 & 39 \\
Pelatih SSB 2 & & &
\end{tabular}

Berdasarkan hasil tabel penilaian observasi model latihan sepakbola bagi anak usia 10-12 tahun dengan latihan menggunakan cone, ball passing, ball controll dimasukkan ke dalam norma kategori. Berikut penyajian norma kategori pada Tabel 2.

Tabel 2. Penghitungan Normatif Kategorisasi

\begin{tabular}{ccc}
\hline Formula & Batasan & Kategori \\
\hline $\mathrm{X}<(\mu-1,0 \sigma)$ & $\mathrm{X}<25$ & Kurang \\
$(\mu-1,0 \sigma) \leq \mathrm{X}<(\mu+1,0 \sigma)$ & $25 \leq \mathrm{X}<35$ & Cukup \\
$(\mu+1,0 \sigma) \leq \mathrm{X}$ & $35 \leq \mathrm{X}$ & Baik \\
\hline
\end{tabular}

Keterangan:

$X=$ jumlah skor subjek; $\mu=$ mean ideal $=1 / 2[(10 \times 4)+(10 \times 1)]=25 ; \sigma=$ standar devisiasi ideal $=1 / 6[(10 \times$ $4)-(10 \times 1)]=5$.

Mengacu pada kategorisasi tersebut maka hasil penilaian observasi model latihan sepakbola bagi anak usia 10-12 tahun latihan ini menggunakan cone, ball passing, ball controll dari para ahli materi dapat diketahui dan disajikan ke dalam tabel 3.

Tabel 3. Distribusi Frekuensi

\begin{tabular}{cccc}
\hline Interval & Kategori & Frekuensi & Persentase \\
\hline $\mathrm{X}<25$ & Kurang & 0 & $0,00 \%$ \\
$25 \leq \mathrm{X}<35$ & Cukup & 0 & $0,00 \%$ \\
$35 \leq \mathrm{X}$ & Efektif & 5 & $100 \%$ \\
& & 5 & $100 \%$ \\
\hline
\end{tabular}

Tabel 3 menunjukkan penilaian observasi ahli materi terhadap model latihan sepakbola bagi anak usia 10-12 tahun latihan dengan menggunakan cone, ball passing, ball controll, tidak ada subjek (0\%) yang 
memandang kurang, tidak ada subjek (0\%) yang memandang cukup, dan 5 responden $(100,00 \%)$ memandang baik. Total nilai para ahli semuanya terletak pada interval $35 \leq \mathrm{X}$, maka pandangan para ahli materi terhadap hasil observasi model latihan sepakbola bagi anak usia 10-12 tahun latihan dengan menggunakan cone, ball passing, ball controll untuk siswa SSB usia 10-12 tahun adalah baik.

Tabel 4. Data Hasil Observasi Keefektifan Uji Coba Skala Besar Model Latihan Sepakbola Bagi Anak Usia 10-12 Tahun Latihan dengan Menggunakan Cone, Ball Passing, Ball Controll

\begin{tabular}{|c|c|c|c|c|c|c|c|c|c|c|c|}
\hline \multirow{2}{*}{ Ahli Materi } & \multicolumn{10}{|c|}{ Item Klasifikasi } & \multirow{2}{*}{ Total Nilai } \\
\hline & 1 & 2 & 3 & 4 & 5 & 6 & 7 & 8 & 9 & 10 & \\
\hline Pakar 1 & 4 & 4 & 4 & 4 & 4 & 4 & 4 & 4 & 4 & 4 & 40 \\
\hline Pakar 2 & 4 & 4 & 4 & 4 & 4 & 4 & 4 & 4 & 4 & 4 & 40 \\
\hline Pakar 3 & 4 & 4 & 4 & 4 & 4 & 4 & 4 & 4 & 4 & 4 & 40 \\
\hline Pelatih SSB 1 & 4 & 4 & 4 & 4 & 4 & 4 & 4 & 4 & 4 & 4 & 40 \\
\hline Pelatih SSB 2 & 4 & 4 & 4 & 4 & 4 & 4 & 4 & 4 & 4 & 4 & 40 \\
\hline
\end{tabular}

Berdasarkan hasil tabel penilaian observasi keefektifan model latihan sepakbola bagi anak usia 10-12 tahun latihan dengan menggunakan cone, ball passing, ball controll dimasukkan ke dalam norma kategori. Berikut penyajian norma kategori pada tabel 5.

Tabel 5. Distribusi Frekuensi

\begin{tabular}{cccc}
\hline Interval & Kategori & Frekuensi & Persentase \\
\hline $\mathrm{X}<25$ & Kurang & 0 & $0,00 \%$ \\
$25 \leq \mathrm{X}<35$ & Cukup & 0 & $0,00 \%$ \\
$35 \leq \mathrm{X}$ & Efektif & 5 & $100 \%$ \\
& & 5 & $100 \%$ \\
\hline
\end{tabular}

Tabel 5 menunjukkan penilaian observasi ahli materi terhadap model latihan sepakbola bagi anak usia 10-12 tahun latihan dengan menggunakan cone, ball passing, ball controll, tidak ada subjek (0\%) yang memandang kurang baik/efektif, tidak ada subjek (0\%) yang memandang cukup baik/efektif, dan 5 responden $(100,00 \%)$ memandang baik/efektif. Total nilai para ahli semuanya terletak pada interval $35 \leq \mathrm{X}$, maka pandangan para ahli materi terhadap hasil observasi model latihan sepakbola bagi anak usia 10-12 tahun latihan dengan menggunakan cone, ball passing, ball controll untuk siswa SSB usia 10-12 tahun memandang baik/efektif.

Tabel 6. Data Hasil Observasi Uji Coba Skala Besar Model Latihan Sepakbola Bagi Anak Usia 10-12 Tahun Pada Latihan Ball Controll dengan Kaki Bagian Luar, Kaki Bagian Dalam, Kaki Bagian Paha

\begin{tabular}{lcccccccccccc}
\hline \multicolumn{1}{c}{ Ahli Materi } & \multicolumn{1}{c}{ Item Klasifikasi } & Total Nilai \\
\cline { 2 - 9 } & 1 & 2 & 3 & 4 & 5 & 6 & 7 & 8 & 9 & 10 & \\
\hline Pakar 1 & 4 & 4 & 4 & 4 & 4 & 4 & 4 & 4 & 4 & 4 & 40 \\
Pakar 2 & 4 & 4 & 4 & 4 & 4 & 4 & 4 & 4 & 4 & 4 & 40 \\
Pakar 3 & 4 & 4 & 3 & 4 & 4 & 4 & 4 & 4 & 4 & 4 & 39 \\
Pelatih SSB 1 & 4 & 4 & 3 & 4 & 4 & 4 & 4 & 4 & 4 & 4 & 39 \\
Pelatih SSB 2 & 4 & 4 & 4 & 4 & 4 & 4 & 4 & 4 & 4 & 4 & 40 \\
\hline
\end{tabular}

Berdasarkan hasil tabel penilaian observasi model latihan sepakbola ball control dengan kaki bagian luar, kaki bagian dalam, kaki bagian paha dimasukkan ke dalam norma kategori. Berikut penyajian norma kategori pada tabel 7.

Tabel 7. Distribusi Frekuensi

\begin{tabular}{|c|c|c|c|}
\hline $\begin{array}{l}\text { Interval } \\
\end{array}$ & Kategori & Frekuensi & Persentase \\
\hline$X<25$ & Kurang & 0 & $0,00 \%$ \\
\hline $25 \leq X<33$ & Cukup & 0 & $0,00 \%$ \\
\hline $33 \leq X$ & Efektif & 5 & $100 \%$ \\
\hline \multicolumn{2}{|c|}{ Jumlah } & 5 & $100 \%$ \\
\hline
\end{tabular}

Tabel 7 menunjukkan penilaian observasi ahli materi terhadap model latihan sepakbola bagi anak usia 10-12 tahun latihan pada ball control dengan kaki bagian luar, kaki bagian dalam, kaki bagian paha, tidak ada subjek $(0 \%)$ yang memandang kurang, tidak ada subjek $(0 \%)$ yang memandang cukup, dan 5 responden $(100,00 \%)$ memandang baik. Total nilai para ahli semuanya terletak pada 
interval $35 \leq \mathrm{X}$, maka pandangan para ahli materi terhadap hasil observasi model latihan sepakbola bagi anak usia 10-12 tahun latihan pada ball control dengan kaki bagian luar, kaki bagian dalam, kaki bagian paha untuk siswa SSB usia 10-12 tahun adalah baik.

Tabel 8. Data Hasil Observasi Keefektifan Uji Coba Skala Besar Model Latihan Sepakbola Bagi Anak Usia 10-12 Tahun Pada Latihan Ball Controll denagan Kaki Bagian Luar, Kaki Bagian Dalam,

Kaki Bagian Paha

\begin{tabular}{|c|c|c|c|c|c|c|c|c|c|c|c|}
\hline \multirow{2}{*}{ Ahli Materi } & \multicolumn{10}{|c|}{ Item Klasifikasi } & \multirow{2}{*}{ Total Nilai } \\
\hline & 1 & 2 & 3 & 4 & 5 & 6 & 7 & 8 & 9 & 10 & \\
\hline Pakar 1 & 4 & 4 & 4 & 4 & 3 & 4 & 4 & 4 & 4 & 4 & 39 \\
\hline Pakar 2 & 4 & 4 & 4 & 4 & 4 & 4 & 4 & 4 & 4 & 4 & 40 \\
\hline Pakar 3 & 4 & 4 & 3 & 4 & 4 & 4 & 4 & 4 & 4 & 4 & 39 \\
\hline Pelatih SSB 1 & 4 & 4 & 4 & 4 & 4 & 4 & 4 & 4 & 4 & 4 & 40 \\
\hline Pelatih SSB 2 & 4 & 4 & 3 & 4 & 4 & 4 & 4 & 4 & 4 & 4 & 39 \\
\hline
\end{tabular}

Berdasarkan hasil tabel penilaian observasi keefektifan model latihan sepakbola bagi anak usia 10-12 tahun latihan pada ball control dengan kaki bagian luar, kaki bagian dalam, kaki bagian paha dimasukkan ke dalam norma kategori. Berikut penyajian norma kategori pada table 9.

Tabel 9. Distribusi Frekuensi

\begin{tabular}{|c|c|c|c|}
\hline Interval & Kategori & Frekuensi & Persentase \\
\hline$X<25$ & Kurang & 0 & $0,00 \%$ \\
\hline $25 \leq X<33$ & Cukup & 0 & $0,00 \%$ \\
\hline $33 \leq X$ & Efektif & 5 & $100 \%$ \\
\hline \multicolumn{2}{|c|}{ Jumlah } & 5 & $100 \%$ \\
\hline
\end{tabular}

Tabel 9 menunjukkan penilaian observasi ahli materi terhadap model latihan sepakbola bagi anak usia 10-12 tahun latihan pada ball control dengan kaki bagian luar, kaki bagian dalam, kaki bagian paha, tidak ada subjek (0\%) yang memandang kurang baik/efektif, tidak ada subjek (0\%) yang memandang cukup baik/efektif, dan 5 responden $(100,00 \%)$ memandang baik/efektif. Total nilai para ahli semuanya terletak pada interval $35 \leq \mathrm{X}$, maka pandangan para ahli materi terhadap hasil observasi model latihan sepakbola bagi anak usia 10-12 tahun latihan pada ball control dengan kaki bagian luar, kaki bagian dalam, kaki bagian paha untuk siswa SSB usia 10-12 tahun memandang baik/efektif.

Tabel 10. Data Hasil Observasi Uji Coba Skala Besar Model Latihan Sepakbola Bagi Anak Usia 10-12 Tahun pada Latihan menggunakan Cone, Ball passing, Ball controll

\begin{tabular}{|c|c|c|c|c|c|c|c|c|c|c|c|}
\hline \multirow{2}{*}{ Ahli Materi } & \multicolumn{10}{|c|}{ Item Klasifikasi } & \multirow{2}{*}{ Total Nila } \\
\hline & 1 & 2 & 3 & 4 & 5 & 6 & 7 & 8 & 9 & 10 & \\
\hline Pakar 1 & 4 & 4 & 4 & 4 & 3 & 4 & 4 & 4 & 4 & 4 & 39 \\
\hline Pakar 2 & 4 & 4 & 4 & 4 & 4 & 4 & 4 & 4 & 4 & 4 & 40 \\
\hline Pakar 3 & 4 & 4 & 3 & 4 & 4 & 3 & 3 & 4 & 4 & 4 & 37 \\
\hline Pelatih SSB 1 & 4 & 4 & 3 & 4 & 4 & 4 & 4 & 4 & 4 & 3 & 38 \\
\hline Pelatih SSB 2 & 4 & 4 & 4 & 4 & 4 & 4 & 4 & 4 & 4 & 4 & 40 \\
\hline
\end{tabular}

Berdasarkan hasil tabel penilaian observasi model latihan sepakbola bagi anak usia 10-12 tahun pada latihan menggunakan cone, ball passing and ball controll dimasukkan ke dalam norma kategori. Berikut penyajian norma kategori pada tabel 11.

Tabel 11. Distribusi Frekuensi

\begin{tabular}{cccc}
\hline Interval & Kategori & Frekuensi & Persentase \\
\hline $\mathrm{X}<25$ & Kurang Baik/Efektif & 0 & $0,00 \%$ \\
$25 \leq \mathrm{X}<33$ & Cukup Baik/Efektif & 0 & $0,00 \%$ \\
$33 \leq \mathrm{X}$ & Baik/Efektif & 5 & $100,00 \%$ \\
& Jumlah & 5 & $100,00 \%$ \\
\hline
\end{tabular}

Tabel 11 menunjukkan penilaian observasi ahli materi terhadap model latihan sepakbola bagi anak usia 10-12 tahun pada latihan menggunakan cone, ball passing and ball controll, tidak ada subjek $(0 \%)$ yang memandang kurang, tidak ada subjek $(0 \%)$ yang memandang cukup, dan 5 responden $(100,00 \%)$ memandang baik. Total nilai para ahli semuanya terletak pada interval $35 \leq \mathrm{X}$, 
maka pandangan para ahli materi terhadap hasil observasi model latihan sepakbola bagi anak usia 1012 tahun pada latihan menggunakan cone, ball passing and ball controll untuk siswa SSB usia 10-12 tahun adalah baik.

Tabel 12. Data Hasil Observasi Keefektifan Uji Coba Skala Besar Model Latihan Sepakbola Bagi Anak Usia 10-12 Tahun pada Latihan menggunakan Cone, Ball passing, Ball

\begin{tabular}{|c|c|c|c|c|c|c|c|c|c|c|c|}
\hline \multirow{2}{*}{ Ahli Materi } & \multicolumn{10}{|c|}{ Item Klasifikasi } & \multirow{2}{*}{ Total Nila } \\
\hline & 1 & 2 & 3 & 4 & 5 & 6 & 7 & 8 & 9 & 10 & \\
\hline Pakar 1 & 4 & 4 & 4 & 4 & 3 & 4 & 4 & 4 & 4 & 4 & 39 \\
\hline Pakar 2 & 4 & 4 & 4 & 4 & 4 & 4 & 4 & 4 & 4 & 4 & 40 \\
\hline Pakar 3 & 4 & 4 & 3 & 4 & 4 & 3 & 3 & 4 & 4 & 4 & 37 \\
\hline Pelatih SSB 1 & 4 & 4 & 3 & 4 & 4 & 4 & 4 & 4 & 4 & 3 & 38 \\
\hline Pelatih SSB 2 & 4 & 4 & 3 & 4 & 4 & 4 & 4 & 4 & 4 & 4 & 40 \\
\hline
\end{tabular}

Berdasarkan hasil tabel penilaian observasi keefektifan model latihan sepakbola bagi anak usia 10-12 tahun pada latihan menggunakan cone, ball passing and ball controll dimasukkan ke dalam norma kategori. Berikut penyajian norma kategori pada tabel 13.

Tabel 13. Distribusi Frekuensi

\begin{tabular}{|c|c|c|c|}
\hline Interval & Kategori & Frekuensi & Persentase \\
\hline$X<25$ & Kurang & 0 & $0,00 \%$ \\
\hline $25 \leq X<33$ & Cukup & 0 & $0,00 \%$ \\
\hline $33 \leq \mathrm{X}$ & Efektif & 5 & $100 \%$ \\
\hline \multicolumn{2}{|c|}{ Jumlah } & 5 & $100 \%$ \\
\hline
\end{tabular}

Tabel 13 menunjukkan penilaian observasi ahli materi terhadap model latihan sepakbola bagi anak usia 10-12 tahun pada latihan menggunakan cone, ball passing and ball controll, tidak ada subjek $(0 \%)$ yang memandang kurang baik/efektif, tidak ada subjek (0\%) yang memandang cukup baik/efektif, dan 5 responden $(100,00 \%)$ memandang baik/efektif. Total nilai para ahli semuanya terletak pada interval $35 \leq \mathrm{X}$, maka pandangan para ahli materi terhadap hasil observasi model sepakbola bagi anak usia 10-12 tahun pada latihan menggunakan cone, ball passing and ball controll untuk siswa SSB usia 10-12 tahun memandang baik/efektif.

Tabel 14. Data Hasil Observasi Uji Coba Skala Besar Model Latihan Sepakbola Bagi Anak Usia 1012 Tahun pada Latihan Ball Passing dengan Turning menggunakan Cone sebagai lawan

\begin{tabular}{lcccccccccccc}
\hline \multicolumn{1}{c}{ Ahli Materi } & \multicolumn{10}{c}{ Item Klasifikasi } & \multicolumn{1}{c}{ Total Nilai } \\
\cline { 2 - 13 } & 1 & 2 & 3 & 4 & 5 & 6 & 7 & 8 & 9 & 10 & 40 \\
Pakar 1 & 4 & 4 & 4 & 4 & 4 & 4 & 4 & 4 & 4 & 4 & 40 \\
Pakar 2 & 4 & 4 & 4 & 4 & 4 & 4 & 4 & 4 & 4 & 4 & 37 \\
Pakar 3 & 4 & 4 & 3 & 4 & 4 & 3 & 3 & 4 & 4 & 4 & 38 \\
Pelatih SSB 1 & 4 & 4 & 3 & 4 & 4 & 4 & 4 & 4 & 4 & 3 & 38 \\
Pelatih SSB 2 & 4 & 4 & 3 & 4 & 4 & 4 & 4 & 4 & 4 & 3 & 38 \\
\hline
\end{tabular}

Berdasarkan hasil tabel penilaian observasi model latihan sepakbola bagi anak usia 10-12 tahun pada latihan ball passing dengan turning menggunakan cone sebagai lawan dimasukkan ke dalam norma kategori. Berikut penyajian norma kategori pada tabel 15.

Tabel 15. Distribusi Frekuensi

\begin{tabular}{cccc}
\hline Interval & Kategori & Frekuensi & Persentase \\
\hline $\mathrm{X}<25$ & Kurang & 0 & $0,00 \%$ \\
$25 \leq \mathrm{X}<33$ & Cukup & 0 & $0,00 \%$ \\
$33 \leq \mathrm{X}$ & Efektif & 5 & $100 \%$ \\
& & 5 & $100 \%$ \\
\hline
\end{tabular}

Tabel 15 menunjukkan penilaian observasi ahli materi terhadap model latihan sepakbola bagi anak usia 10-12 tahun pada latihan ball passing dengan turning menggunakan cone sebagai lawan, tidak ada subjek $(0 \%)$ yang memandang kurang, tidak ada subjek $(0 \%)$ yang memandang cukup, dan 5 responden $(100,00 \%)$ memandang baik. Total nilai para ahli semuanya terletak pada interval $35 \leq \mathrm{X}$, maka pandangan para ahli materi terhadap hasil observasi model latihan sepakbola bagi anak usia 10- 


\section{JORPRES (Jurnal Olahraga Prestasi), 15 (1), 2019 - 26}

Kafung Mikail, Suharjana

12 tahun pada latihan ball passing dengan turning menggunakan cone sebagai lawan untuk siswa SSB usia 10-12 tahun adalah baik.

\section{SIMPULAN}

Dari hasil penilaian para ahli materi, pelatih sebagai praktisi di lapangan dan kuesioner siswa terhadap model latihan sepakbola bagi anak usia 10-12 tahun di sekolah sepakbola SSB yang dikembangkan dapat disimpulkan bahwa: Model latihan sepakbola bagi anak usia 10-12 tahun di sekolah sepakbola SSB ini dinilai baik dan efektif. Adapun model latihan sepakbola bagi anak usia 10-12 tahun sebagai berikut: Produk dari penelitian pengembangan ini berupa model latihan sepakbola bagi anak usia 10-12 tahun di sekolah sepakbola yang berisikan 5 mode latihan, yaitu: (a) Latihan Ball Passing, (b) Latihan Ball Controll, (c) Latihan Ball Feeling, (d) Latihan Ball Dribbling, (e) Latihan Coordinationt. Respon siswa SSB yang menjadi sampel dalam penelitian ini, yaitu siswa mampu melakukan model latihan yang diajarkan dan ingin melakukannya kembali pada saat latihan berikutnya, sehingga secara umum siswa memberikan respon yang positif terhadap model latihan sepakbola bagi anak usia 10-12 tahun di sekolah sepakbola SSB. Model latihan sepakbola bagi anak usia 10-12 tahun di sekolah sepakbola SSB yang dikembangkan layak untuk digunakan.

Produk model latihan sepakbola bagi anak usia 10-12 tahun di sekolah sepakbola SSB yang dikembangkan layak untuk digunakan. Produk model latihan teknik dasar sepakbola bagi anak usia 10-12 tahun sehingga dapat memperkaya pengalaman dan meningkatkan kemampuan siswa dalam bermain sepakbola dan memilii teknik dasar sepakbola dengan baik.

\section{DAFTAR PUSTAKA}

Ambarukmi, D. H. (2007). Pelatihan pelatih fisik level 1. Jakarta: Kemenpora.

Bompa, T.O. (1999). Periodization of strength, the new wave in strength training. Toronto, Ontario, Canada: Veritas Publishing.

Borg, W. R. \& Gall, M. D. (1983). Education research (4^thed.). New York: Longman Inc.

Coerver, W. (1985). Sepak Bola (Program Pembinaan Pemain Ideal). Jakarta PT. Gramedia.

Giriwijoyo,Y.S.S.,dkk. (2005). Manusia dan olahraga. Bandung: Penerbit ITB.

Harsono. (1988). Coaching dan Aspek-aspek Psikologi dalam Coaching. Jakarta. CV. Tambak Kusuma.

Irianto, D.P. (2004). Pedoman praktis berolahraga. Yogyakarta: Andi Offset.

Komarudin, K. (2015). Permainan sepakbola sebagai wahana pembinaan sikap sosial anak usia sekolah dasar. Jurnal Pendidikan Jasmani Indonesia, 3(1). doi:https://doi.org/10.21831/jpji.v3i1.6170

Lutan, R. (2000). Dasar-dasar kepelatihan. Jakarta: Departemen Pendidikan dan Kebudayaan.

McMorris, T. \& Hale, T. (2006). Coaching science (Theory into practice). Chichester: John Wiley \& Sons Ltd.

Metzler \& Michael W. (2000). Instructional models for physical education. Needham Heights: Allyn and Bacon.

Rosdiani, D. (2012). Model pembelajaran langsung dalam pendidikan jasmani dan kesehatan. Bandung: Alfabeta.

Sagala, S. (2012). Konsep dan makna pembelajaran. Bandung: Alfabeta.

Sajoto. 1995. Pembinaan Kondisi Fisik Dalam Olahraga. Jakarta; Departemen Pendidikan dan Kebudayaan.

Samsudin. (2008). Pembelajaran motorik di taman kanak-kanak. Jakarta: Prenada Media Group.

Scheunemann, T. (2012). Kurikulum \& pedoman dasar sepakbola Indonesia. Jakarta: PSSI.

Stratton, G. (2004). Youth soccer from science to performance. London and New York: Routledge. 
JORPRES (Jurnal Olahraga Prestasi), 15 (1), 2019 - 27

Kafung Mikail, Suharjana

Sucipto. (2000). Sepak Bola. Jakarta: Depdikbud.

Suharjana. (2007). Latihan beban. Yogyakarta: FIK UNY.

Sukadiyanto. (2010). Pengantar teori dan metodologi melatih fisik. Yogyakarta: Fakultas Ilmu Keolahragaan UNY.

Wahjoedi. (2001). Landasan evaluasi pendidikan jasmani. Jakarta: Raja Grafindo. 